\title{
The poetry of Antarctic sound and the sound of Antarctic poetry
}

\author{
Elizabeth Leane ${ }^{1}$
}

In 1996, the Antarctic Treaty System officially recognised the value of creative engagements with the continent, citing 'the contribution of writers, artists and musicians' as a key means of 'promotion of understanding and appreciation of the values of Antarctica'. ${ }^{2}$ It is often hard to separate these different forms of imaginative response - textual, visual, aural - in the creative works that emerge from the continent. This is particularly the case in recent decades when various national programs have launched 'artists and writers' schemes, which send people working in diverse artistic modes to the continent. Drawn together by their similar tasks and their newness to the Antarctic community, these 'artists-in-residence' tend to form their own bonds, and learn about each other's mediums of expression. Musicians and sonic artists become inspired by written narratives of exploration; visual artists begin to write poetry on the side; poets draw on the vocabulary of art and music in their attempts to express their experiences of the continent; novelists look to musicians as the basis for characters. ${ }^{3}$

Thus an analysis of the relationship between sound, music and literature in an Antarctic context could fruitfully proceed by a number of different approaches. Those with expertise in both literary studies and musicology might draw on the well-developed, theoretically complex field of study concerned with the connections between music and literature - sometimes termed 'melopoetics' - to shed light on this relationship. For others, like me, whose background is primarily literary, perhaps the most straightforward starting point is the representation of music — or, at least, its production and performance - in literary texts.

There is no shortage of examples. Antarctic fiction (my own speciality) furnishes plenty of relevant material: short stories and novels that deal with - that in some cases, you might say are even about — music and sound. An obvious

\footnotetext{
1 Associate Professor Elizabeth Leane, School of Humanities, University of Tasmania, Private Bag 41, Hobart, TAS 7000, Elizabeth.Leane@utas.edu.au.

2 Antarctic Treaty Consultative Meeting XX, Res. 2.

3 Music, art and writing, of course, do not exhaust the range of creative response to the continent: they are used as shorthand here for the wide range of artforms practised by those who have visited the continent, including film-making, photography, sculpture, dance and choreography.

4 Paul Steven Scher (2004) Essays on literature and music (1967-2004), eds Walter Bernhart and Werner Wolf. Rodopi, Amsterdam, p. 471.
} 
example is Graham Billing's novel Forbush and the penguins. ${ }^{5}$ A minor New Zealand classic, and often taught in schools there, it was adapted for screen, with John Hurt as the main character, in the early 1970s. The novel focuses almost entirely on a single character, Richard Forbush, a biologist who stays alone in Shackleton's hut at Cape Royds for a summer to monitor a nearby adelie penguin population. He is also an amateur musician who takes his clarinet when he journeys south (it becomes a guitar in the film). Over his months of isolation, he begins to assemble a strange and elaborate musical instrument of his own invention, which he calls the 'Penguin Major Polyphonic Music Machine'. ${ }^{6}$ The machine is constructed from bits and pieces guiltily pilfered from the hut itself, and its core component is a 'water-bottle xylophone made from Shackleton's sauce bottles and Professor T Edgeworth David's test tubes'. ${ }^{7}$ As Forbush's time in the hut continues he experiences a growing existential crisis triggered by the unrelenting cycles of birth and death among the local penguin population, and plays his instrument in a vain attempt to ward off this crisis. The eccentricity of the music machine he builds reflects his state of mind.

Music and sound have engaged another New Zealand novelist writing more recently about Antarctica, Laurence Fearnley. Her novel Degrees of Separation deals partly with a 'sonic artist' travelling with the New Zealand Antarctic program. ${ }^{8}$ She suffers from a serious case of imposter symdrome, unable to accept the legitimacy of her own work in the face of scientists and field training officers — those with 'proper jobs' ${ }^{9}$ But here I want to discuss Fearnley's earlier short story called 'The Piper and the Penguin'. ${ }^{10}$ The title references the well-known image of the same name, which is reproduced in the text. The photograph comes from from the Scottish Antarctic Expedition of 1902-04, and shows a kilted bagpiper playing to a penguin surreptitiously tied to his ankle. Like her novel, Fearnley's story focuses on a fictional composer-in-residence with the New Zealand program. ${ }^{11}$ This composer, Max, sends increasingly cryptic packages back from the continent to his wife Kathleen in Auckland. Kathleen, a visual artist who shares not only her name but also her occupation with history's most famous Antarctic widow, receives a series of enigmatic photographs, beginning with 'The Piper and the Penguin'. Before long, she identifies the connection between the photographs: they are all 'images of sound'. The last package, sent after Max has spent time in the field, contains a cassette tape. Having played it, Kathleen believes it to be blank. But when her husband arrives home, and

5 Graham Billing (1965) Forbush and the penguins. Holt, Rinehard and Winston, New York, 1966 edn.

Billing (1965) Forbush and the penguins, p. 86.

Billing (1965) Forbush and the penguins, p. 87.

Laurence Fearnley (2006) Degrees of Separation. Penguin New Zealand, Auckland.

Fearnley (2006) Degrees of Separation, p. 72.

10 Laurence Fearnley (1998) 'The Piper and the Penguin'. In Bill Manhire, ed. (2004) The wide white page: writers imagine Antarctica. Victoria University Press, Wellington, pp. 246-58.

11 Fearnley (1998) 'The Piper and the Penguin', p. 246. 
listens to the tape for hours and days on end, she realises it is not blank but a recording of silence. Their relationship too is silenced, as her husband becomes increasingly non-communicative, withdrawn, and obsessed with his enigmatic encounter with the sounds of Antarctica. Max himself seems to become a silent continent.

The travails of a composer travelling on an arts fellowship are central to American writer Lucy Jane Bledsoe's recent novel The Big Bang Symphony. ${ }^{12} \mathrm{Her}$ composer, Mikala Wilbo, heads to the South Pole with the American program to write a symphony inspired by the cosmological work underway there: her rather ambitious brief to the National Science Foundation (NSF) is that she will 'musically represent the Big Bang'. Once arrived - and still dealing with a past personal trauma - she is unable to write a note. She practises scales, plays Bach and procrastinates. While she can see the music, she tells a fellow expeditioner, she is unable to 'create sound' with it. Her Antarctic experiences, however, eventually remove the obstacles to her expression, and the novel ends with the central characters listening to an orchestral performance of her piece, 'a song of aching beauty ... that carrie[s] all the epic hope of that continent ${ }^{\prime}{ }^{13}$

These are just a few examples of Antarctic fiction in which music and sound play a central role, but even this small sample space suggests some shared thematic preoccupations. Both Fearnley's and Bledsoe's stories highlight the anxieties of the composer sent south with an official artistic mission - but this may, of course, be a version of the novelist's own literary anxieties, disguised and distanced from the author by being projected onto a different artform. More fundamental is the sense in these literary texts that musical creativity is both an instinctive response to the continent - the way, in fact, of accessing or expressing its most essential 'voice' — and simultaneously the source of frustration, obsession and near madness.

Readers too experience a frustration, in the inability of the narrative to actually present the sonic or musical event at its heart. Readers can't, of course, hear the symphony that gives Bledsoe's novel its name and nicely resolved ending; we can't listen to the recordings that Fearnley's sonic artist makes, or even the particular kind of silence that holds the composer Max spellbound; and we don't know what noises Forbush manages to produce out of his water-bottle xylophone.

This absence is characteristic of prose fiction dealing with music and sound, which must be represented textually, through words on the page. But it doesn't characterise all literature — for sound and music bear a much more immediate relationship to the other, more aural modes of literary production: drama and

12 Lucy Jane Bledsoe (2010) The Big Bang Symphony. Terrace-University of Wisconsin Press, Madison WI.

13 Bledsoe (2010) The Big Bang Symphony, p. 330. 
poetry. I could write here about Antarctic drama, theatre and performance there is plenty of material. The history of theatrical uses of Antarctica is rich, if a little bizarre at times, and both sound and music are pivotal. There is, for example, the production Australis, or the City of Zero (1900): this was staged to celebrate Australia's Federation, and proposed, tongue-in-cheek, that the national capital be located at the South Pole. ${ }^{14}$ Feted as an 'entirely Original, Musical and Spectacular, Pantomimic Extravaganza of the Future', it incorporated a full operatic chorus and orchestra, and featured, among other things, 'A Comic Ballet of Polar Animals' ${ }^{15}$ Equally peculiar but more disturbing is the opera Das Opfer ('The Sacrifice'), ${ }^{16}$ with a 12-tone musical score by the composer Winfried Zillig (a student of Arnold Schoenberg), and a libretto adapted from the prizewinning play Die Südpolexpeditions des Kapitans Scott (1929), by Reinhard Goering. The opera, which dealt with the final days of Robert F Scott's last expedition and featured a singing, dancing chorus of penguins, closed after only a few performances, possibly due to Nazi displeasure. ${ }^{17}$ Better known is a slightly later response to Scott's expedition, Douglas Stewart's mid-century verse play for radio The Fire on the Snow. In its original 1941 broadcast, the play featured only the sound of wind in addition to human voices. ${ }^{18}$ Then there is the off-offBroadway musical comedy Meet the Real Ernest Shackleton (2004), ${ }^{19}$ in which the banjo takes a prominent part; it was this instrument, salvaged from the wreck of the Endurance, which helped relieve the tedium of Shackleton's stranded men. Like most theatre, Antarctic performances almost always combine literary text and sound, and often music.

But the relationship between literature and sound that I want to focus on here, after this rather long preamble, is the more inextricable one achieved in poetry - the mode of literature in which the sound of words, the rhythm of speech, the repetitions and the pauses, are most central. To put it simply: poets tend to be interested in sound. It is striking, but not suprising, how many poems about the continent deal explicitly with sound or music. Here, I have space to examine only a handful, from diverse historical, literary and geographical contexts.

14 Bernard Epinasse, and JC Williamson (1900) Australis; or the City of Zero. Libretto. J Andrew, Sydney. ML Q792.4/W 1-53, Mitchell Library, State Library of New South Wales, Sydney, p. 72.

15 Epinasse and Williamson (1900) Australis; or the City of Zero, pp. 1, 11.

16 Winfried Zillig (1937) Das Opfer: Oper von Reinhard Goering. Libretto by Reinhard Goering, piano-vocal score. Bärenreiter-Verlag, Kassel, 1960.

17 Hanne Nielsen and Elizabeth Leane (2013) "Scott of the Antarctic" on the German stage: Reinhard Goering's Die Südpolexpedition des Kapitans Scott'. New Theatre Quarterly 29(3): 278-93, p. 290.

18 Gus Worby (1996) 'The Fire on the Snow: The Penguin's Egg'. In Douglas Stewart The Fire on the Snow. Currency, Paddington, NSW: ix-xviii, p. xii.

19 'Meet the Real Ernest Shackleton: a Comedy About Antarctica'. Written and dir. Michael Christian, choreographed by Ron Schwinn, music by Terry Radigan. Perf. Sande Shurin Theatre, New York City, 9-26 Sept 2004 . 
At the risk of being predictable, I will begin with Samuel Taylor Coleridge's 'The Rime of the Ancient Mariner,' originally published in $1798 .^{20}$ As the first example of Antarctic poetry, and arguably Antarctic literature, in English, Coleridge's gothic horror ballad has exerted an influence on the later literature of the continent that is probably second to no other text. It is also, incidentally, the earliest piece of Antarctic literature that has been put to music. Musical responses have varied considerably. They range from a cantata by John Francis Barnett, performed at the Birmingham Triennial Musical Festival in 1867 (see Figure 1), to the closing, 13-minute number of the 1984 album Powerslave by the heavy metal rock group Iron Maiden. It is not surprising that the poem is so readily adapted as song lyrics, because its rhyme and rhythm are so strong - a point to which I will return.

In 'The Rime of the Ancient Mariner,' the old sailor of the poem's title tells of a sea journey from Britain down to the South Polar regions and back again. In the Antarctic, the mariner for no obvious reason shoots a friendly albatross, and is thereafter subjected to all manner of hideous supernatural punishments including the final penance of having to re-tell his tale indefinitely to people he mysteriously singles out. On this occasion he relates his story to an unwilling but enthralled wedding guest - the whole gothic tale takes place against the ironic background of the 'merry din' of the nuptial feast which the guest should be attending. In Gustave Doré's famous illustrations to an 1876 edition of Coleridge's poem, the corresponding image foregrounds the musicians (see Figure 2).

Only a relatively small section of this long poem is actually set in the Antarctic - about ten of over 140 stanzas. The following three occur at the point in the poem where the ship first enters the South Polar regions.

And now there came both mist and snow,

And it grew wondrous cold:

And ice, mast-high, came floating by,

As green as emerald.

And through the drifts the snowy cliffs

Did send a dismal sheen:

Nor shapes of men nor beasts we ken -

The ice was all between.

The ice was here, the ice was there,

The ice was all around:

It cracked and growled, and roared and howled,

Like noises in a swound. (1. 51-62).

20 Samuel Taylor Coleridge (1798) 'The Rime of the Ancient Mariner'. In John Leonard, ed. (2003) Seven centuries of poetry in English, 5th edn. Oxford University Press, Melbourne, pp. 310-24. 

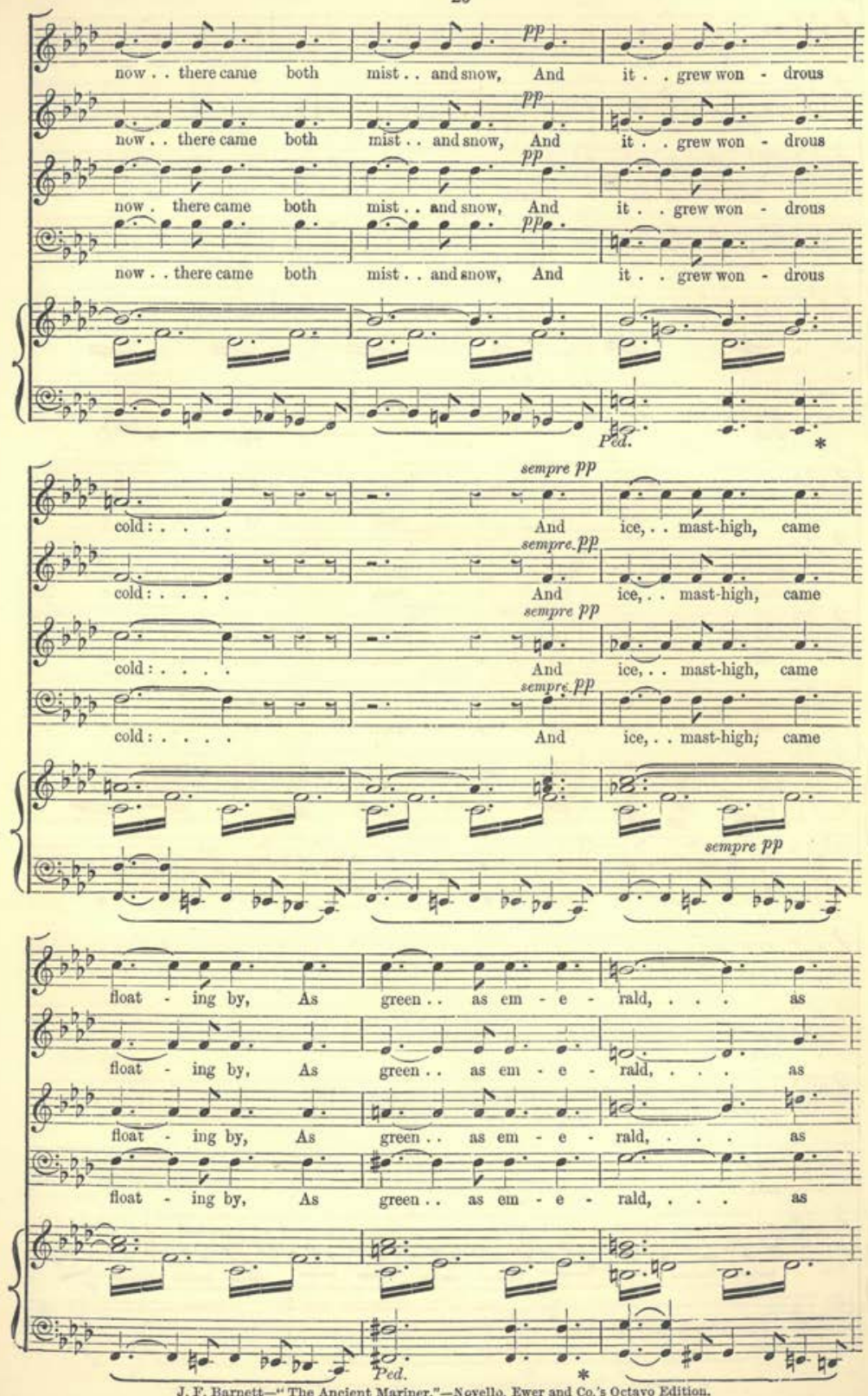

Figure 1. Score for John Francis Barnett's cantata 'The Ancient Mariner: a cantata' (Novello, London, n.d.). 


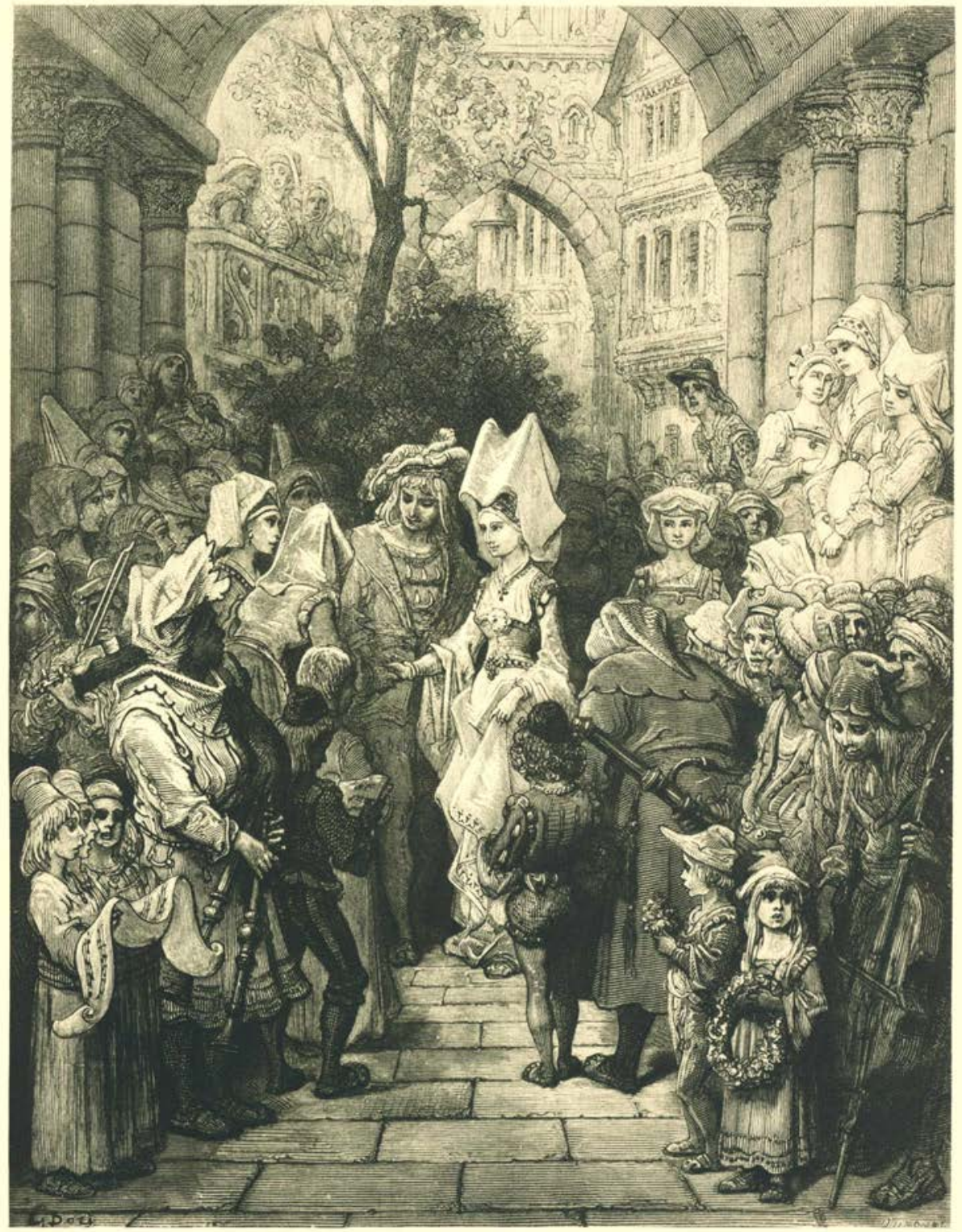

4

Figure 2. 'Red as a Rose is the Bride', one of Gustave Doré's illustrations from Coleridge's 'The Rime of the Ancient Mariner', originally published in an 1876 edition of the poem. 
These stanzas present the Antarctic through different senses - tactile, visual, and finally aural. They are dominated by the presence of ice, which is simultaneously beautiful and threatening. Although the ice is at first perceived as jewel-like, very soon it becomes oppressive in its unrelenting presence, relieved only by disquieting sounds. The marginal gloss (which Coleridge added in his 1817 edition of the poem) notes that these lines describe 'The land of ice, and of fearful sounds where no living thing was to be seen'. While visually the ice is disturbingly lifeless, aurally it is the opposite: the noises themselves are fearful precisely because they uncannily mimic those of a living creature - a fierce, mutable and monstrous one.

But it is the poem's own sounds as much as the sounds the mariner explicitly reports that characterise the Antarctic in the poem. The 'Rime' has an alternating tetrameter and trimeter metre, an a-b-c-b rhyme scheme (with some irregular stanzas), as well as plentiful internal rhyme, alliteration and repetition - and all are evident in these lines. These features are typical of the ballad genre, but in this poem about ice they take on particular resonances. The rhythmic repetition of the same words - 'The ice was here, the ice was there' - in these stanzas give a sense of the all-pervasiveness of the sea-ice surrounding the ship. The sense of confused, intimidating noises that the last two lines evoke is reinforced by that strange final word, 'swound' - an archaic term for 'swoon' or fainting fit — which itself confuses the rhyme. As Susan Wolfson notes in her essay 'Sounding Romantic', visually it seems to suggest not only the word 'sound' but also 'wound' and 'swoon' (par. 16), and the first-time reader might hesitate over whether it does indeed rhyme with 'around', or is merely an eyerhyme - a visual resemblance: 'swound is a ghost of sound, a rhyme-word that lurks in the aural field without precipitating ... However one speaks it, the stress of swound hits the ear as a wounded sound' (par. 16). ${ }^{21}$

The sound of 'swound', however, is only a faint echo of what is achieved in the poem's title with the single word, 'Rime'. This is, of course, another of Coleridge's archaisms - an early spelling of the word we now write as 'rhyme' — but it is a particularly significant one. In the decades of revisions that Coleridge made to the poem, he removed many other archaisms in the text and the title, but not this one. One obvious reason for this is the significance of the pun on this word, which also can mean 'hoar-frost' - the ice deposited on surfaces by freezing fog or mist. In Romantic weather: the climates of Coleridge and Baudelaire, Arden Reed devotes a whole chapter just to teasing out this pun. ${ }^{22}$ Reed argues convincingly that the Mariner himself, whose beard 'with age is hoar' (1. 620),

21 Susan Wolfson 'Sounding Romantic'. "“Soundings of Things Done": the poetry and poetics of sound in the Romantic ear and era'. Romantic Circle Praxis Series. Online, available at http://www.rc.umd.edu/praxis/ soundings/about.html.

22 Arden Reed (1983) Romantic weather: the climates of Coleridge and Baudelaire. University Press of New England, Hanover. 
and whose appearance startles those he encounters, is himself a 'piece of rime, or frozen mist', condemned to wander the earth continually telling the same tale, in a kind of 'suspended animation' - frozen in time. ${ }^{23}$ Thus while only a short section of the tale takes place in the Antarctic, the Antarctic inhabits the tale-teller himself. But Reed goes on to point out a more complex relationship evoked by the pun. The Mariner's story, repeated over and over again to selected unwilling listeners, is related not in prose but in rhyme, a literary device which itself achieves its effect through constant repetition of sound; so, sound, like the Mariner, is in a sense frozen, held in suspended animation, through rhyme. The 'rime' — or hoar-frost — of the title, argues Reed, becomes a metaphor for 'frozen language'. ${ }^{24}$

When Coleridge wrote the 'Rime', he had never left Britain - never even crossed the English channel. He took most of his polar imagery from highlatitude travel narratives, both north and south. He had read James Cook's account of his circumnavigation of the South Polar region, and one of his school teachers, William Wales, had been a navigator on the journey. ${ }^{25}$ Cook did not see the continent, only its surrounding waters and ice; nothing was known at this time of the interior plateau. Thus Coleridge's Antarctica is noisy, full of the cracks and groans of icebergs and sea ice.

With the exploration of the continent itself in the early 20th century, silence emerged as a key component of poetic responses. In some cases, these responses can be interpreted as attempts to ward off silence. For men sledging for days on the relatively featureless plateau, silence could be oppressive. Poetry and song, recited aloud or in one's head, formed a welcome release. Apsley CherryGarrard recommended the use a volume of poems in the field 'because it gave one something to learn by heart and repeat during the blank hours of the daily march'. ${ }^{26}$ 'Sledging songs' - motivational verses composed on the march, recounting the challenges of the journey and celebrating its achievements, often put to the tune of a sea-shanty or music-hall song - were particularly important. Their rhyme and rhythm matched the repetitive onward tramp of sledging, and their personal content and well-known melodies gave a homely familiarity to the alien icescape. Morton Moyes, who spent more than two months alone in a hut on an ice shelf during the Australasian Antarctic Expedition, identified silence as one of the worst of his trials. Even music he played on the gramophone 'seemed only to emphasise the heavy burden of silence that gave no peace'. Yet, when his release from this oppression finally arrived, it was heralded by music of a different kind:

23 Reed (1983) Romantic weather, pp. 154-5, 178.

24 Reed (1983) Romantic weather, p. 180.

25 Bernard Smith (1992) Imagining the Pacific: in the wake of the Cook voyages. Melbourne University Press, Carlton, Vic., pp. 135-71.

26 Apsley Cherry-Garrard (1922) The worst journey in the world. Picador-Macmillan, London 1994, p. 203. 
Then came the day when I felt the solitude had at last beaten me. As I sat writing up my journal, I thought I heard a sledging song, one of those rollicking ditties we used to sing to boost our morale. I stood up, alarmed by the fancy, shaking with a sense of confusion. I'm going dippy, I thought. This is it. I stared stupidly about me. I heard the singing again, as faint and elusive as the far-off note of a bugle. ${ }^{27}$

The return of his companions was announced not by a visual but an aural signal, a breaking of the silence of his isolation.

For some explorers silence was not an oppressor but an active participant in the Antarctic experience, one who constantly drew or lured the expeditioner towards the south. In Edward Wilson's 'The Barrier Silence', published in the South Polar Times in $1902,{ }^{28}$ silence signifies mystery and secrecy, the enigmatic Pole he hoped to reach. In 'The Silence Calling,' often attributed to Douglas Mawson but actually the last verse of Robert Service's poem 'L'Envoi' (1909) slightly adapted by Mawson for Antarctic purposes, 'the frozen music of staryearning heights' is likewise a lure. ${ }^{29}$ The fatal journey of Scott, Wilson and company in 1911-12 made this metaphor less tenable, and gave polar silence other associations. In Stewart's retelling of this fateful polar journey, The Fire on the Snow, silence unsurprisingly signifies death: 'The living thing is the word / And the thing dead is silence. / These men of their own accord / Move away into silence / Their skis soft on the snow'. ${ }^{30}$ At the end of the century this silence/death equation is still very evident in Antarctic poetry. Chris Wheat's 'Antarctica', which deals with a man succumbing to HIV/AIDS, begins: 'Antarctica is a continent without music, / as silent as starched sheets' ${ }^{31}$ The connection is particularly strong in poems written in response to the Erebus disaster, such as Michael Wilson's 'In Memory of Erebus'32 and Mary Dilworth's 'Air Disaster, Antarctica', ${ }^{33}$ which is why, I think, it is so effective that Bill Manhire framed his recent, more uplifting poetic commemoration of the crash as 'Erebus Voices' ${ }^{34}$ Another strong association is between silence and white: Alexandra Bates's poem, 'Rondeau, Ridge A, Antarctica', begins, 'Can you hear the sounds of titanium white? / Shh, we're trying to paint the quiet'.$^{35}$ Of course, silence and quiet are not exactly the same thing; the latter has more

\footnotetext{
27 Morton Moyes (1964), as told to George Dovers and D'Arcy Niland. Season in Solitary. Walkabout 30(10) October: 20-3, p. 23.

28 Edward Wilson (1902) 'The Barrier Silence'. South Polar Times 3: 151.

29 Douglas Mawson / Robert Service (1977) 'The Silence Calling'. Canberra Times 7 June, p. C5.

30 Douglas Stewart (1944) The Fire on the Snow. pp. 1-42 in The Fire on the Snow and The Golden Lover: two plays for radio. Angus and Robertson, Sydney, p. 9.

31 Chris Wheat (1996) 'Antarctica'. Meanjin 55(1): 132-7.

32 Michael Wilson (1989) 'In Memory of Erebus'. Muse (Arts Council of Australia, ACT Division) 83 Nov:

33 Mary Dilworth (1993) 'Air Disaster, Antarctica'. Riding to a Paradise. Jacaranda, Milton, p. 76.

34 Bill Manhire (2005) 'Erebus Voices'. Lifted. Victoria University Press, Wellington: pp. 40-1.

35 Alexandra Bates (2010) ‘Rondeau, Ridge A, Antarctica'. Meanjn 69(1): 226.
} 
peaceful resonances, something that is evident in Frank Debenham's poem 'The Quiet Land' (1956). ${ }^{36}$ But the difference between the silent continent and the quiet land is the topic for another essay.

One Antarctic poem which places a very high value on silence is Denis Glover's 'How Doth My Good Cousin Silence?', published in 1963:

The one time silent regions of the Pole

Are now vociferous, upon the whole.

Where Amundsen stormed in with cold deceit

And Scott's grim team toiled on to outface defeat

Now Neptune navy boys, pre-heated upper lip,

Roar in to land on Coca-Cola Strip

And great Sir Hillary's ice-breaker jaw

Drums in with tractors. What a bore.

O Pole, thou should'st be silent as before.

But, quoth the London Committee, and the Ross

Sea Committee, and the chewing-gum boys, and the

$\mathrm{Ob}$ and the Grab and the IGY scientists

and sickeners, and Life and Time, and all the

quarrel-thickeners,

\section{Nevermore. ${ }^{37}$}

In this playful and satirical poem, Antarctic silence signifies not death but purity, and humanity's intrusion on the continent is figured in terms of noise pollution. Perhaps ironically, from a 21 st-century perspective, the speaker is disillusioned with the cushiness of mid-century Antarctic activity and the associated bureaucracy. Bookending the text are quotations from the work of two seminal poetic figures. The title is a line drawn from Shakespeare's Henry IV, Part II; in that play the character of Silence is mostly true to his name - the exception being the bawdy drinking songs he favours when under the influence. Like the continent, he shifts readily from near-silence to boisterousness. At the other end of the poem, of course, is the famous refrain from 'The Raven', by Edgar Allan Poe - who, as a writer of prose fiction, rivals Coleridge for his influence on Antarctic literature.

In between, Glover's poem itself uses rhythm and rhyme to reinforce its contrast of the silent, pure, pre-exploration Pole with the corporatised, tamed Antarctica of the late 1950s - the period of the International Geophysical Year (IGY). The

36 Frank Debenham (1956) 'The Quiet Land'. In June Debenham Backs, ed. (1992) The Quiet Land: the Antarctic diaries of Frank Debenham. Bluntisham Books, Bluntisham, p. 10.

37 Denis Glover (1963) 'How Doth My Good Cousin Silence?' Denis Glover's bedside book. Reed, Wellington, p. 122. Reproduced with kind permission from the Denis Glover estate and the copyright holder, Pia Glover. 
poem takes the rough form of a sonnet, although the octave (first eight lines) is made up, unusually but appropriately enough, of heroic couplets. The turn of the sonnet pivots around that ninth line — 'O Pole, though should'st be silent as before' - which, with its faux-Shakespearean language, suggests an element of self-mockery in its expression of nostalgia. Then, when all the voices crowd in upon the continent in the last five lines - voices of committees organising the Fuchs-Hillary expedition, of Russian ice-breakers, of scientists, journalists and bureaucrats - the form turns to something like prose, signifying the mundane and banal, before Poe's raven ironically silences them all with the pessimistic pronouncement that the Pole will be silent no more.

Not all Antarctic poetry in recent years posits such a stark binary between the symbolic silence of the continent and the noise of human interest and inhabitation. I want to turn for my last example to a late 20th-century poem which foregrounds music in its attempt to evoke an Antarctic landscape. This is 'The Music Makers', by Caroline Caddy, a Western Australian poet who travelled south on a writer's residency with the Australian national program in the mid-1990s. The poem was published in her collection Antarctica in 1996.

Over ice that's humped

like buried harps and pianos

through wind scoops

melt pots of ancient

Chinese music

all day we peer into the distances

of a bushman's song

about a tree mistaken

for a man.

The sun slides on we stop

in the huge ocarina

of Antarctica.

La da da da da I explain

ni naw ni naw ni he says.

We stamp our feet and blow into

our cupped hands

the colours of Neptune Jupiter and Mars

leaning in

to hear. ${ }^{38}$

Landscape and music seem to become one in this poem. Not only do the speaker and her companion journey through an icescape shaped like buried musical

38 Caroline Caddy (1996) 'The Music Makers'. Antarctica. Fremantle Arts Centre, South Fremantle, p. 69. Thanks to Caroline Caddy for permission to quote from this poem, and for her comments on the poem. 
instruments, the continent itself takes on the form of an ancient wind instrument - the ocarina - with wind-scoops in the ice acting as the finger holes. The actions of the expeditioners too - stamping feet, blowing into cupped hands - produce a kind of music, and their words, emptied of linguistic meaning, become nonsense lyrics.

'The Music Makers' gains a layer of complexity from its title, which references Edward Elgar's choral composition of the same name (1912), which in turn sets to music the text of British poet Arthur O'Shaughnessy's 'Ode', from his 1874 collection Music and Moonlight. ${ }^{39} \mathrm{O}^{\prime}$ Shaugnessy's poem, which famously begins 'We are the music makers, / And we are the dreamers of dreams', highlights both the isolation and the significance of the poet or 'music maker'. Caddy's poem suggests a complex relationship between the poet and the environment - both 'music makers' of a kind. Commenting on her poem, Caddy notes that 'in Antarctica there is no particular rhyme in the wind and no rhythm as we know it in the cracking of the ice, and all our effforts to describe it to ourselves can only be an echo of ourselves' ${ }^{40}$ With its lack of any obvious meter or rhyme scheme, absence of expected punctuation and slightly irregular spacing of words, the poem suggests a primarily visual rather than aural pattern. Its conclusion, Caddy reflects, is a 'synesthesia of colours of the late sun in Antarctica', evoking 'the colours of the planets as we seem them', Gustav Holst's orchestral suite The Planets and the philosophical concept of 'the music of the spheres'. This 'transposition of senses' is for the poet an effect of the vastness and unknowability of the Antarctic. ${ }^{41}$

I could give many other examples of recent Antarctic poems in which music and sound - or their absence - play a prominent part. But my intention is not to be exhaustive; rather, it is to establish poetry as not merely a way of textually representing the sounds of the Antarctic, but as itself a form of sonic response to the continent. It is, of course, both of these things simultaneously, and that is a key part of its power. In addition, these poems indicate the range of possible engagements with Antarctic sound. The continent is a growling beast in Coleridge's poem; the silent backdrop to the rousing tunes of expeditioners in heroic-era sledging songs; the passive auditor of a chatterbox humanity in Glover's sonnet; and an enormous natural instrument in Caddy's 'Music Makers'. Antarctica has inspired diverse poetic voices, and, as long as the continent means something to humanity, it unlikely that these will fall silent.

39 Arthur O'Shaugnessy (1874) 'The Music Makers'. In Caroline Blyth, ed. (2009) Decadent verse: an anthology of Late Victorian poetry, 1872-1900. Anthem, London, pp. 501-3.

40 Caroline Caddy 2014 letter to the author.

41 Caroline Caddy 2014 letter to the author. 
This text is taken from Antarctica: Music, sounds and cultural connections, edited by Bernadette Hince, Rupert Summerson and Arnan Wiesel, published 2015 by ANU Press, The Australian National University, Canberra, Australia. 